\title{
Serum magnesium and calcium in preeclampsia: a comparative study at the Korle-Bu Teaching Hospital, Ghana
}

This article was published in the following Dove Press journal:

Integrated Blood Pressure Control

16 August 2017

Number of times this article has been viewed

\author{
Ebenezer Owusu Darkwa' \\ Charles Antwi-Boasiako ${ }^{2}$ \\ Robert Djagbletey' \\ Christian Owoo' \\ Samuel Obed ${ }^{3, \dagger}$ \\ Daniel Sottie ${ }^{4}$ \\ 'Department of Anaesthesia, \\ University of Ghana School of \\ Medicine and Dentistry, ${ }^{2}$ Department \\ of Physiology, University of Ghana \\ School of Biomedical and Allied \\ Health Sciences, ${ }^{3}$ Department \\ of Obstetrics and Gynaecology, \\ University of Ghana School of \\ Medicine and Dentistry, College \\ of Health Sciences, ${ }^{4}$ Department \\ of Anaesthesia, Korle-Bu Teaching \\ Hospital, Accra, Ghana
}

tSamuel Obed passed away on May 12,2017
Correspondence: Ebenezer Owusu Darkwa

Department of Anaesthesia, University of Ghana School of Medicine and Dentistry, College of Health Sciences, PO Box 4236, Accra, Ghana

Tel +233244670149

Email eoddarquah@yahoo.co.uk
Background: A large percentage (16\% of maternal mortality in developed countries, compared to $9 \%$ in developing countries), is due to hypertensive disorders in pregnancy. The etiology of preeclampsia remains unknown, with poorly understood pathophysiology. Magnesium and calcium play an important role in vascular smooth muscle function and therefore a possible role in the development of preeclampsia.

Aim: We aimed to compare serum magnesium and total calcium levels of preeclamptic and normal pregnant women at the Korle-Bu Teaching Hospital in Ghana.

Patients and methods: A comparative cross-sectional study involving 30 normal pregnant and 30 preeclamptic women with $>30$ weeks gestation and aged 18-35 years, was conducted at the Korle-Bu Teaching Hospital. Magnesium and calcium were determined using a flame atomic absorption spectrometer.

Results: Mean serum magnesium and total calcium levels in preeclamptic women were $0.70 \pm 0.15$ and $2.13 \pm 0.30 \mathrm{mmol} / \mathrm{L}$, respectively. Mean serum magnesium and total calcium levels in normal pregnant women were $0.76 \pm 0.14$ and $2.13 \pm 0.35 \mathrm{mmol} / \mathrm{L}$, respectively. There was a statistically nonsignificant difference in serum magnesium and total calcium in preeclamptic women compared to normal pregnant women, with $p$-values of 0.092 and 0.972 , respectively. Conclusion: Serum magnesium and total calcium, therefore, seem not to differ in preeclamptic women compared to normal pregnant women in Ghana.

Keywords: electrolytes, maternal deaths, pregnant, hypertension, Ghanaian women

\section{Introduction}

Preeclampsia is one of the commonest etiologies of fetal and maternal mortality and morbidity. ${ }^{1}$ The incidence of preeclampsia in developing nations is estimated to be $4-18 \% .^{2}$ Thus, $16 \%$ of all maternal mortality in developed countries and $9 \%$ of maternal mortalities in Asia and Africa are said to be due to hypertensive disorders in pregnancy. ${ }^{3}$ Moreover, $18 \%$ of 724 total maternal deaths at the Korle-Bu Teaching Hospital between 1984 and 1994 were due to hypertensive disorders in pregnancy, including preeclampsia. ${ }^{4} \mathrm{~A}$ worldwide perinatal and neonatal mortality rate of $10 \%$ is associated with preeclamptic disorders, with prematurity as the commonest cause of the neonatal deaths. ${ }^{5}$ Current evidence suggests that the endothelial dysfunction seen in preeclamptic pregnant women may persist years after the episode, and therefore preeclamptic women may be at high risk of cardiovascular diseases later in life. ${ }^{6}$

Though the etiology of preeclampsia remains unclear, many theories suggest abnormal placental implantation and abnormal trophoblastic invasion as possible causes. ${ }^{7}$ The molecular basis of this condition is unresolved in literature. ${ }^{8}$ It has been postulated 
that fluctuations in maternal serum ions may be the precipitating cause of elevated blood pressures in preeclampsia. ${ }^{9,10}$ Dietary deficiency of mineral ions has been shown to have a harmful effect on the pregnant mother and growing fetus and possibly complicate preeclampsia. ${ }^{11}$ Dietary deficiency of magnesium has been established to play a role in blood pressure regulation and hence development of preeclampsia. ${ }^{12}$ Evidence supporting routine magnesium supplementation for all pregnant women has not been substantiated by research, though most studies have reported reduced magnesium levels in pregnancy and worse levels in preeclampsia. ${ }^{13-18}$ However, other studies have also reported a nonsignificant change in the serum magnesium levels of preeclamptic women compared to normal pregnant women. ${ }^{19-21}$

Various studies have also reported reduced serum calcium levels in preeclampsia compared to normal pregnant women. ${ }^{18,20-24}$ Calcium supplementation has been reported to half the risk of development of preeclampsia. ${ }^{25}$ Kanagal et $\mathrm{al},{ }^{25}$ in their study on calcium supplementation in pregnancy, recognized that daily calcium supplementation of $1.5-2 \mathrm{~g}$ reduced the blood pressure, prevented the development of preeclampsia in normotensive pregnant women as well as reduced morbidity and mortality, a finding supported by Hofmeyr et $\mathrm{al}^{26}$ in their systematic review on calcium supplementation in pregnant women at the community level. Other studies, however, noted a nonsignificant difference in serum levels of calcium in preeclampsia compared to normotensive pregnant women. ${ }^{19,27-29}$ In a prospective study, Levine et $\mathrm{al}^{30}$ also observed that calcium supplementation during pregnancy does not prevent the development of preeclampsia in healthy nulliparous women.

The serum calcium and magnesium picture in preeclampsia remains uncertain. We therefore sought to compare serum total calcium and magnesium levels of preeclamptic and normal pregnant women at the Korle-Bu Teaching Hospital in Ghana.

\section{Patients and methods Study design}

A comparative cross-sectional study was undertaken from March to June 2016 at the Korle-Bu Teaching Hospital, Ghana.

\section{Study site}

The Korle-Bu Teaching Hospital is the largest tertiary referral hospital in Ghana with 17 clinical and diagnostic departments and a total bed capacity of 2,000, out of which 350 are in the Department of Gynaecology and Obstetrics. The hospital has a daily outpatient attendance of $\sim 1,500$ patients, out of whom $\sim 100$ are antenatal patients. About 10,000 to 12,000 deliveries are conducted per year at the hospital.

\section{Study population}

All normal pregnant and preeclamptic women with gestations $>30$ weeks and aged between 18 and 35 years inclusive, visiting the antenatal clinic at the Department of Obstetrics and Gynaecology, constituted the target population, except pregnant women with renal disorders, chronic hypertension, gestational or preexisting diabetes mellitus, and those on magnesium and/or calcium therapy. Preeclampsia was diagnosed using a systolic blood pressure $\geq 140 \mathrm{mmHg}$ and a diastolic blood pressure $\geq 90 \mathrm{mmHg}$ plus a random urine sample proteinuria $\geq 1+$ on dipstick. ${ }^{31}$

\section{Sample size and recruitment}

The sample size was determined based on a formula by Charan and Biswas ${ }^{32}$ considering a mean serum magnesium level of $0.58 \mathrm{mmol} / \mathrm{L}$ in preeclamptic women compared to $0.73 \mathrm{mmol} / \mathrm{L}$ in normal pregnant women ${ }^{33}$ at a power of $80 \%$ and a $5 \%$ significance level.

Sixty pregnant women comprising 30 normal pregnant and 30 preeclamptic women with $>30$ weeks of gestation and between the ages of 18 and 35 years inclusive, who met the inclusion criteria were recruited consecutively and included in the study after obtaining written informed consent.

\section{Procedures}

After obtaining an informed consent, participants' demographic characteristics (age, weight and height) were recorded on a structured data collection sheet. The blood pressure of the participants was measured using a mercury sphygmomanometer, twice in each participant 20 minutes apart and averaged, noting the systolic and diastolic blood pressures, from which the mean arterial pressure was calculated using the following formula:

Mean arterial pressure $=$ Diastolic blood pressure $+1 / 3$

(Pulse pressure)

where Pulse pressure $=$ systolic blood pressure - diastolic blood pressure

Using a $5 \mathrm{~mL}$ syringe on a $19 \mathrm{G}$ hypodermic needle, $4 \mathrm{~mL}$ of venous blood was obtained from participants' cubital vein under aseptic conditions. For most serum ions, samples are to be separated within 2 hours as recommended by the Clinical and Laboratory Standards Institute. ${ }^{34}$ Blood samples drawn were immediately placed in a plain test tube and sent to the laboratory for analysis. At the laboratory, the blood samples 
were centrifuged at 4,000 rpm for $\sim 10$ minutes to obtain the serum within 2 hours of sample collection, and subsequently stored at $-20^{\circ} \mathrm{C}$ prior to analysis within 24 hours of sample collection. Serum magnesium and total serum calcium were determined using an atomic absorption spectrometer in an acetylene-air flame (Variant 240FS; Varian Australia Pty Ltd, VIC, Australia) with reference ranges of $0.74-1.03 \mathrm{mmol} / \mathrm{L}$ and $2.12-2.62 \mathrm{mmol} / \mathrm{L}$, respectively.

\section{Statistical analysis}

Data obtained were stored in Microsoft ${ }^{\circledR}$ Access database 2010 and analyzed with SPSS $\AA$ software version 20. The age, parity, body mass index (BMI), systolic blood pressure, diastolic blood pressure and mean arterial pressure of the participants are presented as mean values \pm SDs. The mean serum magnesium and total calcium levels of normal pregnant women and preeclamptic women were compared using an independent $t$-test and are presented in a bar chart. Pearson correlation coefficient was used to determine the association between mean arterial pressure and serum calcium and magnesium levels. A $p$-value $<0.05$ was considered statistically significant.

\section{Ethical issues}

The Ethical and Protocol Review Committee of the University of Ghana School of Medicine and Dentistry, which is affiliated to the Korle-Bu Teaching Hospital approved the study (protocol identification number: CHS-Et/M.4-P4.5/2015-2016).

\section{Results}

Thirty normal pregnant and 30 preeclamptic women with $>30$ weeks of gestation and between the ages of 18 and 35 years were recruited into the study. Table 1 summarizes the characteristics of the pregnant women recruited. In this study, the mean arterial blood pressure $(p<0.001)$, systolic blood pressure $(p<0.001)$ and diastolic blood pressure $(p<0.001)$ of preeclamptic women were significantly higher compared to normal pregnant women.

\section{Mean serum magnesium levels of the study participants}

There was no significant difference $(p=0.092)$ in the mean serum magnesium levels between preeclamptic $(0.70 \pm 0.15 \mathrm{mmol} / \mathrm{L})$ and normal pregnant women $(0.76 \pm 0.14 \mathrm{mmol} / \mathrm{L})$, as shown in Figure 1.

A nonsignificant weak negative correlation was found between mean arterial pressure and serum magnesium levels in preeclamptic women (Pearson correlation coefficient $r=-0.089 ; p=0.639$ ), as shown in Figure 2 .

\section{Mean total serum calcium levels of the study participants}

There was no statistically significant difference $(p=0.972)$ in the mean total serum calcium levels between preeclamptic $(2.13 \pm 0.30 \mathrm{mmol} / \mathrm{L})$ and normal pregnant women $(2.13 \pm 0.35 \mathrm{mmol} / \mathrm{L})$, as shown in Figure 3.

A nonsignificant weak positive correlation was found between mean arterial pressure and serum total calcium levels in preeclamptic women (Pearson correlation coefficient $r=0.047 ; p=0.806$ ), as shown in Figure 4.

There was a nonsignificant negative correlation between serum total calcium and serum magnesium levels in preeclamptic women (Pearson correlation coefficient $r=-0.328$; $p=0.077$ ), as shown in Figure 5 .

\section{Discussion}

Similar to the findings in other studies, ${ }^{35,36}$ our study showed no statistically significant relationship between maternal age and preeclampsia $(p=0.358)$. However, this contrasts with the results of the study by Macdonald-Wallis et al, ${ }^{37}$ which was a very large longitudinal cohort study with a sample size of $\sim 11,651$ women living in a higher income region (Avon,

Table I Summary of participants' characteristics

\begin{tabular}{|c|c|c|c|}
\hline \multirow[t]{3}{*}{ Parameter } & \multirow{2}{*}{$\begin{array}{l}\text { Preeclamptic women } \\
\text { Mean } \pm \text { SD }\end{array}$} & \multirow{2}{*}{$\begin{array}{l}\text { Normal pregnant women } \\
\text { Mean } \pm \text { SD }\end{array}$} & \multirow[t]{3}{*}{$p$-value } \\
\hline & & & \\
\hline & $n=30$ & $n=30$ & \\
\hline Age, years & $30.97 \pm 5.5 I$ & $29.93 \pm 2.60$ & 0.358 \\
\hline Parity & $1.70 \pm 1.42$ & $I .|3 \pm 1.4|$ & 0.567 \\
\hline $\mathrm{BMI}, \mathrm{kg} / \mathrm{m}^{2}$ & $32.03 \pm 7.52$ & $30.50 \pm 5.50$ & 0.374 \\
\hline $\mathrm{SBP}, \mathrm{mmHg}$ & $170.13 \pm 23.69$ & $1 \mid 6.47 \pm 13.38$ & $0.000 *$ \\
\hline $\mathrm{DBP}, \mathrm{mmHg}$ & $106.30 \pm 18.79$ & $67.57 \pm 8.54$ & $0.000 *$ \\
\hline MAP, $\mathrm{mmHg}$ & $126.20 \pm 20.86$ & $83.87 \pm 8.85$ & $0.000 *$ \\
\hline
\end{tabular}

Note: *Significant at $p<0.05$.

Abbreviations: BMI, body mass index; DBP, diastolic blood pressure; MAP, mean arterial pressure; SBP, systolic blood pressure. 


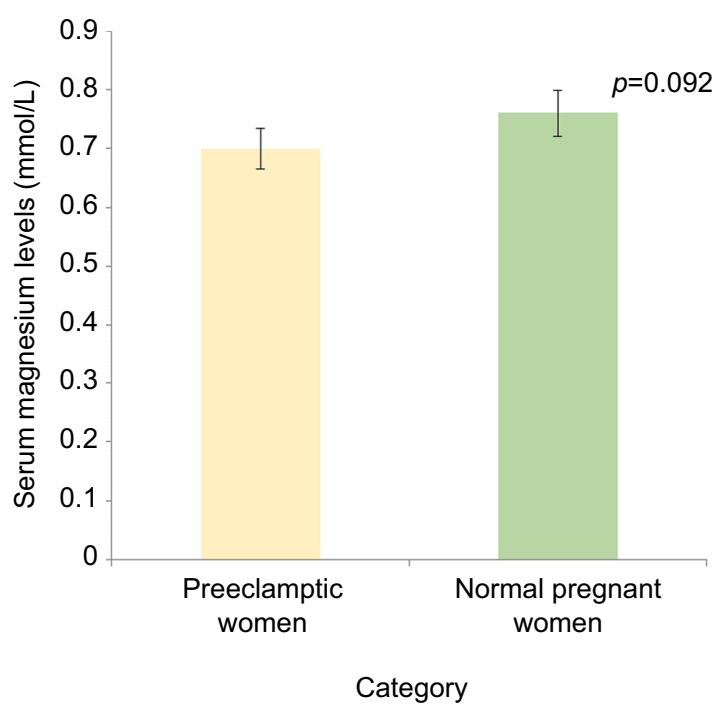

Figure I Mean serum magnesium levels of preeclamptic and normal pregnant women.

England), as compared to our sample population. Additionally, they considered the number of fetuses and the sex of the fetuses being carried by the women, as well as the educational status of the women, factors we did not consider in our study. Therefore, differences in the study design and the characteristics of the patient population studied may possibly account for the differences in the results.

We also noted a nonsignificant relation between preeclampsia and $\operatorname{BMI}(p=0.374)$, as noted by Onyegbule et al, ${ }^{38}$ even though other studies have shown a strong association between BMI and preeclampsia. ${ }^{39-41}$ The findings of Poorolajal and Jenabi ${ }^{39}$ were derived from a meta-analysis, while ours is a case-control cross-sectional study, and this may therefore account for the differences in results. In contrast to our study, Hauger et $\mathrm{al}^{41}$ conducted a large-sample-size multicenter study with possible confounding factors such as inclusion of women with known diabetes, known chronic hypertension and gestational diabetes. The BMI calculation in their study was also based on self-reported recall information of prepregnancy weight and therefore there is a possibility of information bias. There also could be differences in the diet of the studied population. These factors may account for the differences in their findings compared to ours.

The blood pressures (mean systolic, mean diastolic and mean arterial pressures) of the preeclamptic women were significantly elevated compared to the normal pregnant women $(p<0.001)$, as expected per the case definition. Mean arterial pressure has been observed to be predictive of preeclampsia, even though other studies have reported otherwise. ${ }^{42}$

Magnesium and calcium are important cofactors for various enzymatic processes and water balance in cells. ${ }^{43}$ These trace elements play an essential role in vascular smooth muscle tone and contraction, and hence they are vital in blood pressure regulation. ${ }^{44}$

Various studies have reported a decrease in serum magnesium levels as a possible etiology of preeclampsia. . $^{13,14,16-18}$ This evidence is supported by the usefulness of magnesium sulfate therapy for prophylaxis and treatment of seizures associated with preeclampsia/eclampsia ${ }^{45}$ However, this view is not universally accepted, as a Cochrane review involving 2,689 women from seven selected randomized and quasirandomized trials found no high-quality evidence to support the beneficial effect of dietary magnesium supplementation in preventing the development of preeclampsia in pregnant women. ${ }^{46}$

Dietary deficiency of calcium, with consequent reduced serum calcium levels, has been implicated as a cause of preeclampsia in some studies. ${ }^{18,25,26,47,48}$ This has been explained

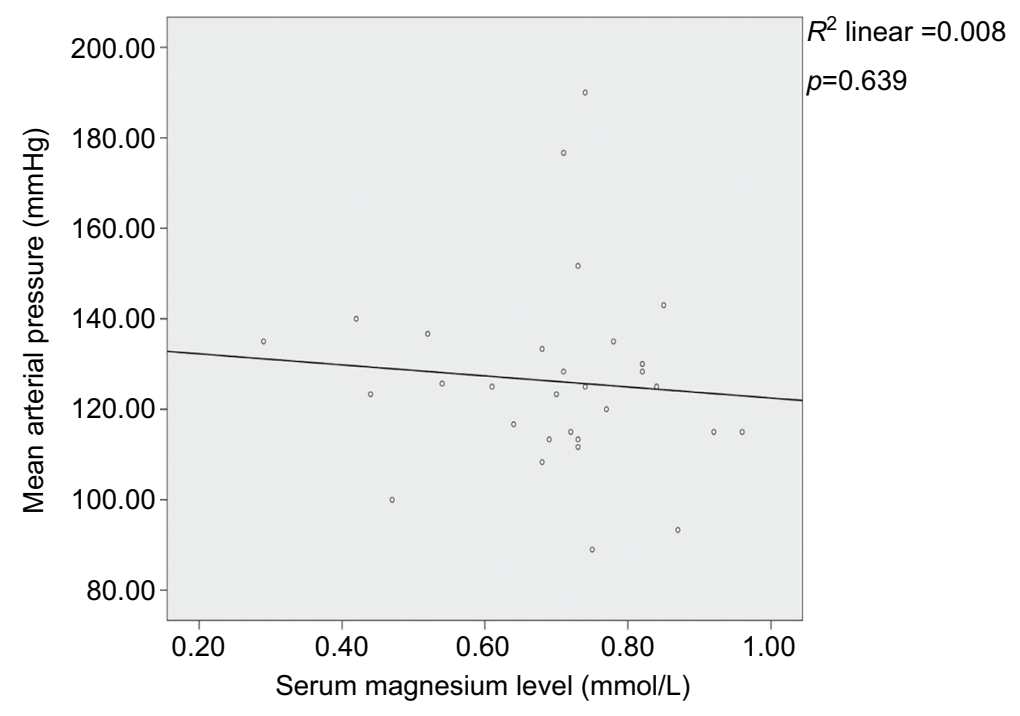

Figure 2 Correlation between serum magnesium levels and mean arterial pressure in preeclamptic women. 


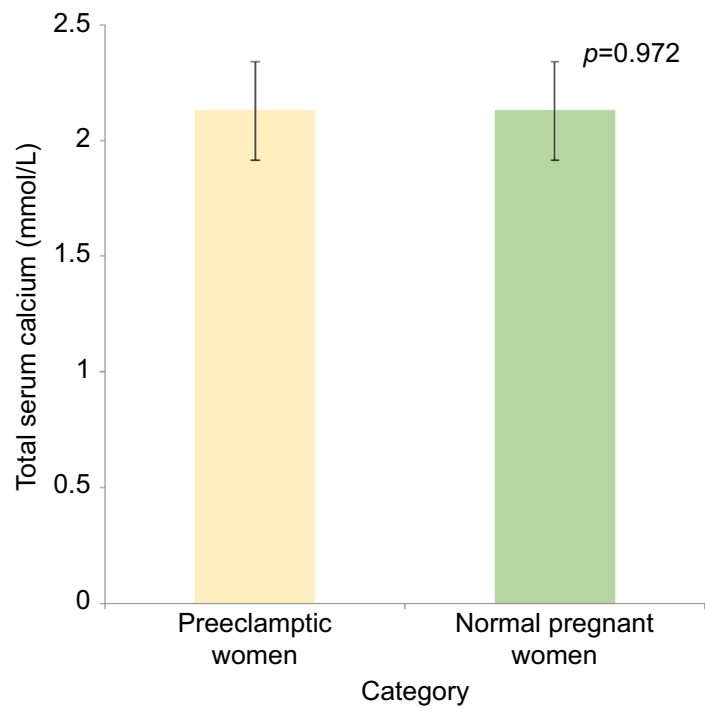

Figure 3 Mean total serum calcium levels of preeclamptic and normal pregnant women. Note: Error bars indicate the confidence interval of the mean of serum calcium levels.

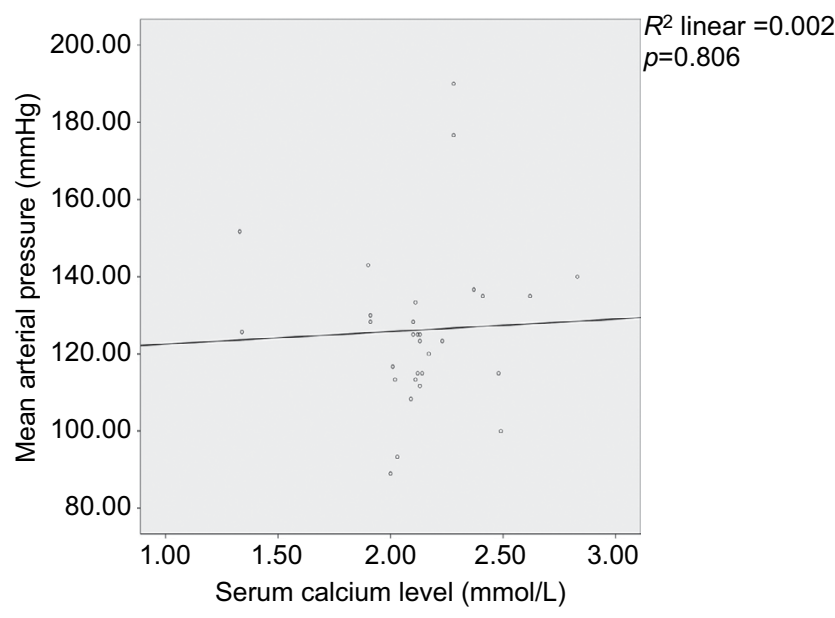

Figure 4 Correlation between total serum calcium levels and mean arterial pressure in preeclamptic women.

by the vasoconstrictive effect caused by reduced serum calcium levels. ${ }^{1,20-24}$ Stimulation of 1,25-dihydroxycholecalciferol has been implicated in this vasoconstrictive mechanism. ${ }^{18}$ This concept of a reduced serum calcium level in preeclampsia is not accepted universally. ${ }^{19,27,29,30,49}$ This is because other studies in preeclamptic women have noted relatively reduced 1,25-dihydroxycholecalciferol levels compared to normal pregnant women,${ }^{50}$ with consequent increase in parathyroid hormone levels, ${ }^{1,20}$ causing reabsorption of calcium from the distal renal tubules and the intestines $\mathrm{s}^{51-53}$ and therefore causing no significant change in the serum calcium levels. Parathyroid hormone also causes renin release with subsequent vasoconstriction and sodium retention in preeclamptic women. ${ }^{54}$

Therefore, hypomagnesemia and hypocalcemia as etiopathologic factors in the development of preeclampsia are not a universal finding in literature. ${ }^{1,20,21,55}$ Various studies from different regions worldwide have reported varying results concerning the role of these trace elements in the etiology of preeclampsia. ${ }^{17,18,56,57}$ In this study, we observed no statistically significant difference in mean total serum calcium and magnesium levels of preeclamptic women compared to normal pregnant women $(p=0.092)$, as found in a study by Magri et al. ${ }^{57}$ Similar studies conducted, including those done in sub-Saharan Africa using the same method of assay (atomic absorption spectrophotometry), in determining serum calcium and magnesium levels also show varying results. ${ }^{38,58,59}$ Ugwuja et al, ${ }^{58}$ in a study conducted among Nigerian women using atomic absorption spectrophotometry for assaying serum calcium and magnesium, found no significant difference in serum calcium but significantly reduced serum magnesium in preeclamptic women as compared to normal pregnant women. Another study conducted among Sudanese women using atomic absorption spectrophotometry for assaying serum calcium and magnesium found a decreased serum calcium level and an increased serum magnesium level ${ }^{59}$ in preeclamptic women as compared to normal pregnant women. These studies, including ours, were conducted in sub-Saharan Africa using the same method of assay for both ions, but the findings were different.

It is therefore possible that the differences in the findings may be attributed to not only differences in the method of assay of serum ions but also differences in dietary habits, genetic pools, as well as the social and economic lifestyle factors of the populations studied. The dietary history and socioeconomic status of the participants in this study were, however, not elucidated. Additionally, differences in sample size may also account for the observed differences in findings.

A nonsignificant negative correlation was observed between serum total calcium and serum magnesium levels in preeclamptic women (Pearson correlation coefficient $r=-0.328 ; p=0.077$ ) in contrast to the findings of Ephraim et al ${ }^{60}$ who noted a nonsignificant positive correlation between serum calcium and serum magnesium levels. A nonsignificant weak negative correlation was observed between mean arterial pressure and serum magnesium levels in preeclamptic women (Pearson correlation coefficient $r=-0.089$; $p=0.639$ ). A nonsignificant weak positive correlation was observed between mean arterial pressure and serum total calcium levels in preeclamptic women (Pearson correlation coefficient $r=0.047 ; p=0.806$ ). Therefore, total serum calcium and serum magnesium may be weak predictors of mean arterial pressure in preeclamptic women. 


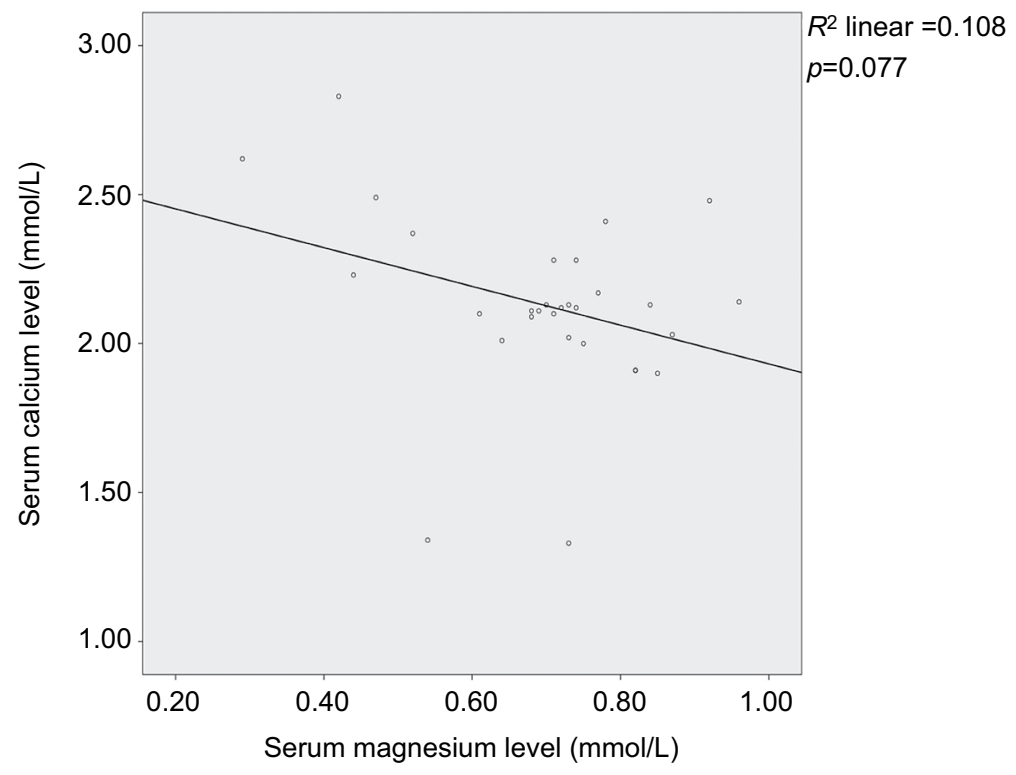

Figure 5 Correlation between serum magnesium levels and total serum calcium levels in preeclamptic women.

\section{Conclusion}

There was no significant difference in the mean serum levels of magnesium and total calcium between preeclamptic and normal pregnant women.

Total serum magnesium and calcium therefore seem not to differ in preeclamptic women in comparison with normal pregnant Ghanaian women.

\section{Acknowledgments}

The authors express their sincere gratitude to all the patients who participated in this study. The authors also convey special thanks to Raymond Essuman and George Aryee for their immense support.

\section{Disclosure}

The authors report no conflicts of interest in this work.

\section{References}

1. Sukonpan K, Phupong V. Serum calcium and serum magnesium in normal and preeclamptic pregnancy. Arch Gynecol Obstet. 2005;273(1): $12-16$.

2. Villar J, Betran A, Gulmezoglu M. Epidemiological basis for the planning of maternal health services. WHO/RHR. 2001;111:298-302.

3. Khan KS, Wojdyla D, Say L, GülmezogluAM, Van Look PF. WHO analysis of causes of maternal death: a systematic review. Lancet. 2006;367(9516): 1066-1074.

4. Lassey A, Wilson J. Trends in maternal mortality in Korle Bu Hospital, 1984-1994. Ghana Med J. 1998;32:910-916.

5. Maynard SE, Karumanchi SA. Angiogenic factors and preeclampsia. Paper presented at: Seminars in Nephrology; 2011.

6. Mutter WP, Karumanchi SA. Molecular mechanisms of preeclampsia. Microvasc Res. 2008;75(1):1-8.

7. Smith RA, Kenny LC. Current thoughts on the pathogenesis of preeclampsia. Obstet Gynaecol. 2006;8(1):7-13.
8. Roberts J, Cooper D. Pathogenesis and genetics of pre-eclampsia. Lancet. 2001;357(9249):53-56.

9. Hanisch CG, Pfeiffer KA, Schlebusch H, Schmolling J. Adhesion molecules, activin and inhibin - candidates for the biochemical prediction of hypertensive diseases in pregnancy? Arch Gynecol Obstet. 2004;270(2):110-115.

10. Bussen S, Sütterlin M, Steck T. Plasma endothelin and big endothelin levels in women with severe preeclampsia or HELLP-syndrome. Arch Gynecol Obstet. 1999;262(3-4):113-119.

11. Raman L, Shatrugna V. Nutrition during pregnancy and lactation. In: Mahtab SB, Prahlad RN, Vinodini R, editors. Textbook of Human Nutrition. New Delhi: IBH; 2002:509.

12. Sarma P, Gambhir S. Therapeutic uses of magnesium. Indian J Pharmacol. 2005;27:7-13.

13. Roberts JM, Myatt L, Spong CY, et al; Eunice Kennedy Shriver National Institute of Child Health and Human Development Maternal-Fetal Medicine Units Network. Vitamins C and E to prevent complications of pregnancy-associated hypertension. $N$ Engl J Med. 2010;362(14):1282-1291.

14. Catov JM, Nohr EA, Bodnar LM, Knudson VK, Olsen SF, Olsen J. Association of periconceptional multivitamin use with reduced risk of preeclampsia among normal-weight women in the Danish national birth cohort. Am J Epidemiol. 2009;169(11):1304-1311.

15. Harrison V, Fawcus S, Jordaan E. Magnesium supplementation and perinatal hypoxia: outcome of a parallel group randomised trial in pregnancy. BJOG. 2007;114(8):994-1002.

16. Nygaard IH, Valbø A, Pethick SV, BøhmerT. Does oral magnesium substitution relieve pregnancy-induced leg cramps? Eur J Obstet Gynecol Reprod Biol. 2008;141(1):23-26.

17. Akinloye O, Oyewale O, Oguntibeju OO. Evaluation of trace elements in pregnant women with pre-eclampsia. Afr J Biotechnol. 2013;9(32):5196-5202.

18. Jain S, Sharma P, Kulshreshtha S, Mohan G, Singh S. The role of calcium, magnesium, and zinc in pre-eclampsia. Biol Trace Elem Res. 2010;133(2):162-170.

19. Golmohammad LS, Amirabi A, Yazdian M, Pashapour N. Evaluation of serum calcium, magnesium, copper and zinc levels in women with pre-eclampsia. Iran J Med Sci. 2008;33(4):231-234.

20. Punthumapol C, Kittichotpanich B. Serum calcium, magnesium and uric acid in preeclampsia and normal pregnancy. $J$ Med Assoc Thai. 2008;91(7):968-973. 
21. Kumru S, Aydin S, Simsek M, Sahin K, Yaman M, Ay G. Comparison of serum copper, zinc, calcium, and magnesium levels in preeclamptic and healthy pregnant women. Biol Trace Elem Res. 2003;94(2):105-112.

22. Akhtar S, Begum S, Ferdousi S. Calcium and zinc deficiency in preeclamptic women. J Bangladesh Soc Physiol. 2011;6(2):94-99.

23. Indumati V, Kodliwadmath MV, Sheela MK. Role of serum electrolytes in pregnancy induced hypertension. J Clin Diagn Res. 2011;5:66-69.

24. Mohieldein AH, Dokem AA, Osman YHM, Idris HM. Serum calcium level as a marker of pregnancy induced hypertension. Sudan J Med Sci. 2007;2(4):245-248.

25. Kanagal DV, Rajesh A, Rao K, et al. Levels of serum calcium and magnesium in pre-eclamptic and normal pregnancy: a study from coastal India. J Clin Diagn Res. 2014;8(7):OC01-OC04.

26. Hofmeyr GJ, Lawrie TA, Atallah ÁN, Duley L. Calcium supplementation during pregnancy for preventing hypertensive disorders and related problems. Cochrane Database Syst Rev. 2010;3:CD001059.

27. Salari Z, Eftekhari N. The comparison of total and ionised serum calcium level in preeclamptic pregnant women and the women with normal pregnancy. J Rafsanjan Univ Med Sci. 2005;4(2):123-128.

28. Vahidrodsari F, Ayaty S, Tourabizadeh A, Ayat-Allahi H, Esmaeli H, Shahabian M. Serum calcium and magnesium in preeclamptic and normal pregnancies; a comparative study. J Reprod Infertil. 2008;9(3): 256-262.

29. Bera S, Siuli R, Gupta S, et al. Study of serum electrolytes in pregnancy induced hypertension. J Indian Med Assoc. 2011;109(8):546-548.

30. Levine RJ, Hauth JC, Curet LB, et al. Trial of calcium to prevent preeclampsia. Obstet Gynecol Surv. 1998;53(1):3-4.

31. American College of Obstetricians and Gynecologists Committee on Obstetric Practice. Practice bulletin\# 33: diagnosis and management of preeclampsia and eclampsia. Obstet Gynecol. 2002;99(1):159-167.

32. Charan J, Biswas T. How to calculate sample size for different study designs in medical research? Indian J Psychol Med. 2013;35(2):121.

33. Adekanle D, Adeyemo O, Adeniyi A, et al. Serum magnesium levels in healthy pregnant and pre-eclamptic patients - a cross-section study. Open J Obstet Gynecol. 2014;4(9):561-568.

34. CLSI. H18-A3: Procedures for the Handling and Processing of Blood Specimens; Approved Guideline. 3 ed. PA, USA: Clinical Laboratory Standards Institute; 2004.

35. Shamsi U, Hatcher J, Shamsi A, Zuberi N, Qadri Z, Saleem S. A multicentre matched case control study of risk factors for preeclampsia in healthy women in Pakistan. BMC Womens Health. 2010;10(1):1.

36. Ganesh KS, Unnikrishnan B, Nagaraj K, Jayaram S. Determinants of pre-eclampsia: a case-control study in a district hospital in South India. Indian J Community Med. 2010;35(4):502-505

37. Macdonald-Wallis C, Lawlor DA, Heron J, Fraser A, Nelson SM, Tilling K. Relationships of risk factors for pre-eclampsia with patterns of occurrence of isolated gestational proteinuria during normal term pregnancy. PLoS One. 2011;6(7):e22115.

38. Onyegbule OA, Meludu SC, Dioka CE, et al. Comparison of serum levels of calcium and magnesium among preeclamptic and normotensive pregnant women at Nnamdi Azikiwe University Teaching Hospital, Nnewi, Nigeria. Int J Res Med Sci. 2014;2(2):404-408.

39. Poorolajal J, Jenabi E. The association between body mass index and preeclampsia: a meta-analysis. J Matern Fetal Neonatal Med. 2016;29(22):3670-3676.

40. Munazza B, Raza N, Naureen A, et al. Liver function tests in preeclampsia. J Ayub Med Coll Abbottabad. 2011;23(4):3-5.
41. Hauger MS, Gibbons L, Vik T, Belizan JM. Prepregnancy weight status and the risk of adverse pregnancy outcome. Acta Obstet Gynecol Scand. 2008;87(9):953-959.

42. Redman C, Beilin L, Bonnar J, Wilkinson R. Plasma-urate measurements in predicting fetal death in hypertensive pregnancy. Lancet. 1976;307(7974):1370-1373.

43. Sissi C, Palumbo M. Effects of magnesium and related divalent metal ions in topoisomerase structure and function. Nucleic Acids Res. 2009;37(3): $702-711$.

44. Walsh SB, Zdebik AA, Unwin RJ. Magnesium: the disregarded cation. Paper presented at: Mayo Clinic Proceedings; 2015.

45. Roberts JM, Balk JL, Bodnar LM, Belizan JM, Bergel E, Martinez A. Nutrient involvement in preeclampsia. J Nutr. 2003;133(5 suppl 2):1684S-1692S.

46. Makrides M, Crowther CA. Magnesium supplementation in pregnancy. Cochrane Database Syst Rev. 2000;2:CD000937.

47. Herrera JA, Arevalo-Herrera M, Herrera S. Prevention of preeclampsia by linoleic acid and calcium supplementation: a randomized controlled trial. Obstet Gynecol. 1998;91(4):585-590.

48. Crowther CA, Hiller JE, Pridmore B, et al. Calcium supplementation in nulliparous women for the prevention of pregnancy-induced hypertension, preeclampsia and preterm birth: an Australian randomized trial. Aust N Z J Obstet Gynaecol. 1999;39(1):12-18.

49. Zemel MB, Zemel PC, Berry S, et al. Altered platelet calcium metabolism as an early predictor of increased peripheral vascular resistance and preeclampsia in urban black women. $N$ Engl $\mathrm{J} \mathrm{Med}$. 1990;323(7):434-438.

50. Hojo M, August P. Calcium metabolism in preeclampsia: supplementation may help. Medscape Womens Health. 1997;2(1):5.

51. Sanchez-Ramos L, Sandroni S, Andres FJ, Kaunitz AM. Calcium excretion in preeclampsia. Obstet Gynecol. 1991;77(4):510-513.

52. Suarez VR, Trelles JG, Miyahira JM. Urinary calcium in asymptomatic primigravidas who later developed preeclampsia. Obstet Gynecol. 1996;87(1):79-82.

53. Taufield PA, Ales KL, Resnick LM, Druzin ML, Gertner JM, Laragh JH. Hypocalciuria in preeclampsia. N Engl J Med. 1987;316(12):715-718.

54. Hacker AN, Fung EB, King JC. Role of calcium during pregnancy: maternal and fetal needs. Nutr Rev. 2012;70(7):397-409.

55. Vafaei H, Dalili M, Hashemi SA. Serum concentration of calcium, magnesium and zinc in normotensive versus preeclampsia pregnant women: a descriptive study in women of Kerman province of Iran. Iran J Reprod Med. 2015;13(1):23.

56. Farzin L, Sajadi F. Comparison of serum trace element levels in patients with or without pre-eclampsia. J Res Med Sci. 2012;17(10):938-941.

57. Magri J, Sammut M, Savona-Ventura C. Lead and other metals in gestational hypertension. Int J Gynaecol Obstet. 2003;83(1):29-36.

58. Ugwuja E, Famurewa A, Ikaraoha C. Comparison of serum calcium and magnesium between preeclamptic and normotensive pregnant Nigerian women in Abakaliki, Nigeria. Ann Med Health Sci Res. 2016;6(1):33-37.

59. Elmugabil A, Hamdan HZ, Elsheikh AE, Rayis DA, Adam I, Gasim GI. Serum calcium, magnesium, zinc and copper levels in Sudanese women with preeclampsia. PLoS One. 2016;11(12):e0167495.

60. Ephraim RKD, Osakunor DNM, Denkyira SW, Eshun H, Amoah S, Anto EO. Serum calcium and magnesium levels in women presenting with pre-eclampsia and pregnancy-induced hypertension: a case-control study in the Cape Coast metropolis, Ghana. BMC Pregnancy Childbirth. 2014;14(1):1-8.

\section{Integrated Blood Pressure Control}

\section{Publish your work in this journal}

Integrated Blood Pressure Control is an international, peer-reviewed open-access journal focusing on the integrated approach to managing hypertension and risk reduction. Treating the patient and comorbidities together with diet and lifestyle modification and optimizing healthcare resources through a multidisciplinary team approach constitute key
Dovepress

features of the journal. This journal is indexed on American Chemical Society's Chemical Abstracts Service (CAS). The manuscript management system is completely online and includes a very quick and fair peerreview system, which is all easy to use. Visit http://www.dovepress.com/ testimonials.php to read real quotes from published authors. 